\title{
Investigation of groundwater quality in "Kiramakodu area" of Point Pedro: Vadamarachi aquifer, Northern Sri Lanka
}

Kugamoorthy Velauthamurty ${ }^{1, *}$, Praveena Raveendran ${ }^{1}$, Kantahsamy Raagulan $^{1}$

\author{
${ }^{1}$ Department of Chemistry, University of Jaffna. \\ ${ }^{*}$ Corresponding Author \\ *Email: kvels@univ.jfn.ac.lk
}

\begin{abstract}
Water is one of the essential part for the existence of life on the earth crust. Over the past decades, demand for the potable water has significantly increased due to the deteriorating anthropogenic activity. Jaffna peninsula completely relies on the groundwater for all the purposes such as domestic, industrial and agriculture. The overpopulation destroyed the freshwater reservoirs and diminishes the natural potable source. This study focuses on a water quality parameters such as $\mathrm{pH}$, turbidity, calcium, magnesium, chloride, sulphate, sodium, potassium, fat, oil and grease (FOG) in vaddamarachi aquifer and calcium (149.17-183.61 ppm), sodium (847.88-1222.99 ppm) and chloride (525.53-924.80 ppm) content of most of the samples are higher than that of Sri Lankan standard for potable water. This study provides the basic information for the future medical study and gives awareness of water conservation in the region.
\end{abstract}

Keywords - contamination, fat, oil and grease, groundwater, industrialization, Jaffna peninsula, water quality parameters.

\section{INTRODUCTION}

Water is the crucial factor for the existence of life, plays a vital role in maintaining human health and welfare. The water sources are gradually degraded by various anthropogenic activities such as urbanization, industrialization, and agricultural activity. Therefore, access to the clean water for the human population is the biggest problem around the globe. Scientists have developed various strategies to remove contaminants. Hence, the safest potable water is available, because of, technological advancement. However, the initial cost for the instrument is high and unable to afford by poor people. Thus, pollution prevention plays a key role and able to provide sustainable natural water sources for the mass population [1-3].

The changes of physicochemical properties of water are considered as water pollution, and if human consumes contaminated water will destroy the wellbeing of the society. The industrial effluents are being discarded into the environment without further treatment in Sri Lanka which causes addition of hazardous components such as toxic heavy metals $(\mathrm{Cr}, \mathrm{As}, \mathrm{Pb}, \mathrm{Hg}$ ), and hazardous organic matters beyond the threshold $[1,4]$. Hence, the human can easily exposure to the hazardous material every day causes serious health issues like cardiovascular diseases, kidney-related problems, neurocognitive diseases and cancer. Besides, the heavy metals also accumulate the life of the environment and transfer via the food chain and finally affect the human. There is no standard regulation for the utilization of the artificial fertilizers, pesticides and weedicides. Farmers also have no depth knowledge to use fertilizers, pesticides, insecticides, herbicides and advance technology. Thus, agriculture is another source of water pollution. The agricultural runoff rises the level of nitrate, phosphate, pesticides, weedicides, heavy metals, and other by-productions in groundwater and lead to adverse impact not only the environment but also human. For instance, the higher amount of nitrate in the drinking water causes the blue baby syndrome. Water pollution is considered as an irreversible process and increase with time. In 2014, in Chunnakam, groundwater was polluted by oil waste from the Power Station and create turmoil regarding water around the Jaffna peninsula. Besides, the waste oil and other automobile waste are being discharged directly to the environment without purification in the Northern Province of Sri Lanka is another source of water pollution [4-5].

Jaffna peninsula is a dry zone located at the longitude of 79 。 $45^{\prime \prime}-80$-20" and latitude 90。30" - 90。50" and depends on the seasonal rainfall. It has four aquifers (Chunnakam (Valikamam area), Thenmaratchi, Vadamaratchi and Kayts) which are recharged every year by seasonal rainfall and aquifers covered by underlain Miocene limestone and close to the Indian Ocean. Earlier researchers [5] carried out a study in Valikamam aquifer area and this study focus on Vadamaratchi aquifer. This study carried out on fat, oil and grease (FOG), but also other parameters such as $\mathrm{pH}$, turbidity, calcium, magnesium, chloride, sulphate, sodium, and potassium. This study will be helpful for the future water management of the Jaffna peninsula and promotes the water safety of each aquifer [3-6].

In this study, Vadamarachi aquifer was selected. Because the oil contamination in Valikamam aquifer has long term socio economic impact. Further, this study will be the platform for the future water conservation and urge water protection as well.

\section{MATERIALS AND METHODOLOGY}

\section{A. Materials}

Ethylenediaminetetraacetic acid (EDTA), Eriochrome Black $\mathrm{T}$, buffer, hexane, Potassium hydroxide, silver nitrate, potassium chromate, hydrochloric acid, and sodium sulphate, 
were purchased from Sigma Aldrich and directly utilized without further purification.

\section{B. Sampling and analysis}

Before sampling, the resident's opinion regarding water quality was taken via face to face conversation, and a service station was spotted in this area as the main source of pollution. Sampling area was shown in figure 1 which consisted of 5 concentric rings with $200 \mathrm{~m}$ difference and overall periphery cover one Kilometer from the concern center. In addition, samples were collected around the intersections of lines of eight directions and the total number of samples were forty. The Latitude and longitude of the sample collection points were given in the figure 2 . The area consists many dug wells and tube wells where the sampling was shown in figure 2 .

\section{Estimation of water quality parameters}

$\mathrm{pH}$ and conductivity were measured using $\mathrm{pH}$ meter and conductivity meter, respectively and followed standard procedure according to the manual. Calcium, magnesium, chloride, and sulphate were measured by standard titration method while potassium and sodium were analyzed by using a flame photometer. In addition, fat, oil and grease (FOG) were determined by the hexane extraction method. The amount of calcium was measured in the presence of magnesium according to the following procedure. The test solution was mixed with $8 \mathrm{M} \mathrm{KOH}$ with the 2:1 volume ratio and kept for 5 minutes with occasional shaking. Then, titration was performed against the standard EDTA solution using Eriochrome Black $\mathrm{T}$ as an indicator. The total amount of calcium and magnesium content was determined by repeating the same procedure and $\mathrm{KOH}$ was replaced by $2 \mathrm{~mL}$

Figure 1: Sample collecting map of Kiramakodu area.

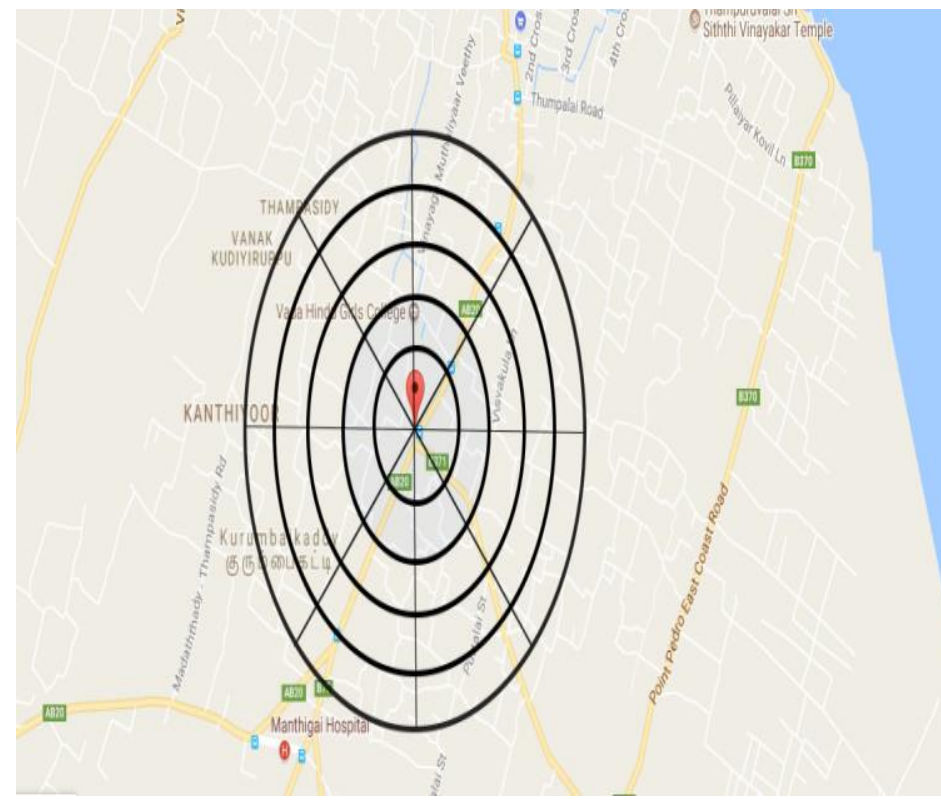

of buffer $\mathrm{pH}=10$. In addition, the amount of sulphate was determined by using back titration for which barium chloride, EDTA and Eriochrome Black $\mathrm{T}$ indicator were used. The chloride content in the water was analyzed by using a silver nitrate solution $(0.01 \mathrm{M})$ and potassium chromate, utilized as an indicator. The sodium and potassium were determined by the standard flame photometric analysis. Samples were acidified by $\mathrm{HCl}(\mathrm{pH}=2)$. Then hexane was added to the sample and maintained 20:1 volume ratio. The mixture was shaken well in a separating funnel and hexane was separated. This process was repeated for three time for each sample. The separated hexane was filtered through anhydrous sodium sulphate and then hexane distilled off and dried in a desiccator for $1 \mathrm{~h}$. The differences in the weight of round bottom flask and sample with round bottom flask were due to the FOG.

\section{RESULTS AND DISCUSSION}

\section{A. $p H$ and electric conductivity (EC) of the water}

$\mathrm{pH}$ is the logarithmic representation of the acid of the solution, ranging from 0-14 can be extended beyond the limit. $\mathrm{pH}$ of the freshwater eco systems have wide environmental $\mathrm{pH}$ range varies which is due to the chemical and biological interaction in the water body. The variation of the $\mathrm{pH}$ stress or kill the freshwater animal, however, animals can tolerate fluctuation of the $\mathrm{pH}$ in the ecosystem. Changes of $\mathrm{pH}$ affects the equilibrium of the dissolve metals, ammonia, hydrogen sulfide and other ions which leads to $\mathrm{pH}$ toxicity. The excessive photosynthesis in aquatic environment rise the $\mathrm{pH}$ and above 9.5 is inappropriate for the aquatic culture. The $\mathrm{pH}$ of the pure water in the air is 5.6 which is due to the presence of the carbon dioxide in the air while the dissolution of the limestone

Figure 2: Mapping of Samples collected places of Kiramakodu area.

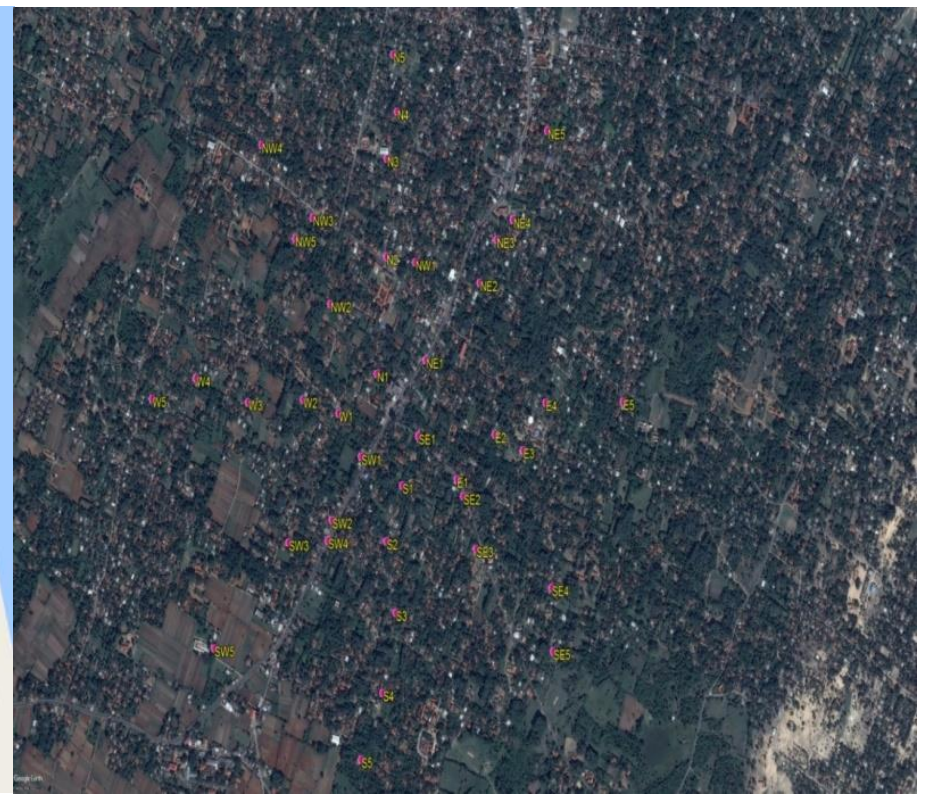


increase $\mathrm{pH}$ significantly. Hence, this process leads alkalinity of the water

[8]. According to the previous study [9]. the limestone consists higher amount of calcite $\left(\mathrm{CaCO}_{3}\right)$, the lower amount of quartz, and other compositions [9]. Hence, limestone may possess impurities like calcium silicates, and calcium magnesium silicates as which can undergo chemical transformation under different weathering shown in equations 1-5. [10]. It was reported earlier [14] reported that the average $\mathrm{pH}$ range of the Jaffna peninsula is 6.7-7.5 and collect the water samples in surface and dug well [11]. The $\mathrm{pH}$ of the aquatic system and body fluid of the organism should be in the ideal range of 6.58.0. Further, out of this range the organism undergoes physiochemical stress and affect not only reproduction but also causes death [12-13]. The lower $\mathrm{pH}$ has its advantage and disadvantage. Lead released from the natural sources causes an imbalance of environment and food chain [14]. The $\mathrm{pH}$ of the groundwater was within the range of 6.98 to 7.86. Some groundwater samples in North, East, and South showed high $\mathrm{pH}$, ranging from 7.60 to 7.86 which is slightly basic while Southeast and South showed low $\mathrm{pH}$, ranging from 6.98 to 7.19. In addition, the Sri Lankan standard for potable water is 6.5-8.5 (Table 2). Hence, the water can be safe for the human and other organisms in the region based on the $\mathrm{pH}$ (Figure. 3a).

Table 2: Comparison of the WHO and SLS standard of some parameters [6-7]

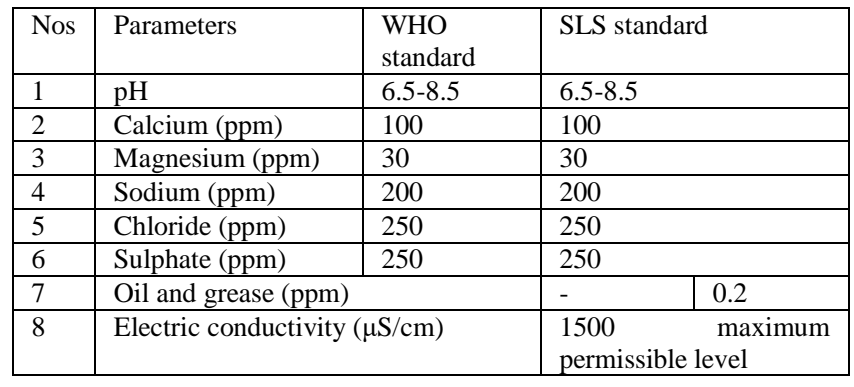

Electrical conductivity is the ability to conduct electricity of 1 $\mathrm{mL}$ water at $25{ }^{\circ} \mathrm{C}$ and its unit is $\mathrm{S} / \mathrm{m}$. The electric conductivity is the parameter give rise the information about the total dissolve charged particle in the water which can be calculated according to the Al Dahaan equation $(\mathrm{TDS}=0.64 \times \mathrm{EC}$ $\mu \mathrm{S} / \mathrm{cm})$. Further, EC of the water is depending on the type of charge constitutions and temperature. In addition, the increment of $1{ }^{\circ} \mathrm{C}$ raise the conductivity about $2-3 \%$. However, no information can get about the constitutional ions from EC and EC give rise the information about the water quality [12-15]. Conductivity is directly related to the concentration of ions, mobility, valance and relative concentration etc. The conductivity of groundwater is high due to the influence of ions such as calcium, magnesium, chloride ions, carbonate, bicarbonate, nitrate, phosphate and sulfate. The land is covered with limestone constituted majorly with $\mathrm{CaCO} 3$ and other components such as $\mathrm{CsSO} 4$, $\mathrm{SiO} 2$. The rainwater washes out both soil and limestone seeps to the aquifer cause the higher conductivity. In addition, the intrusion of seawater also enhanced the conductivity of the groundwater [15].

\section{B. Calcium and magnesium in the groundwater $(G W)$}

Both calcium and magnesium are crucial not only the metabolism of human but also play a major role in the structure of the body. Inadequate consumption causes health risk like strength loss of teeth and bone while excess consumption creates kidney stone. Thus, human continuously consumes calcium via food such as dairy product, sea foods, and some plants. $99 \%$ of the calcium in the body deposited in the bones. Inadequate consumption of the calcium causes health risk like hypertension, osteoporosis, obesity, insulin resistance, and colorectal cancer. Hence, calcium is one of the important nutrients not only in the bone but also other function of the body. Excess amount of calcium intake causes hypercalcaemia, renal insufficiency, and reduce the absorption of the other ions such as iron, zinc, magnesium and etc. The magnesium is the most abandoned cationic mineral in the body and available about 350 enzymes. Low magnesium content causes endothelial dysfunction and other problems in the body [16-17]. The concentration of the Calcium in ground water is in the range of $46.40 \mathrm{ppm}$ to $183.61 \mathrm{ppm}$. According to GIS mapping some samples of East, Southeast showed a very high value of calcium, ranging from $149.17 \mathrm{ppm}$ to 183.61
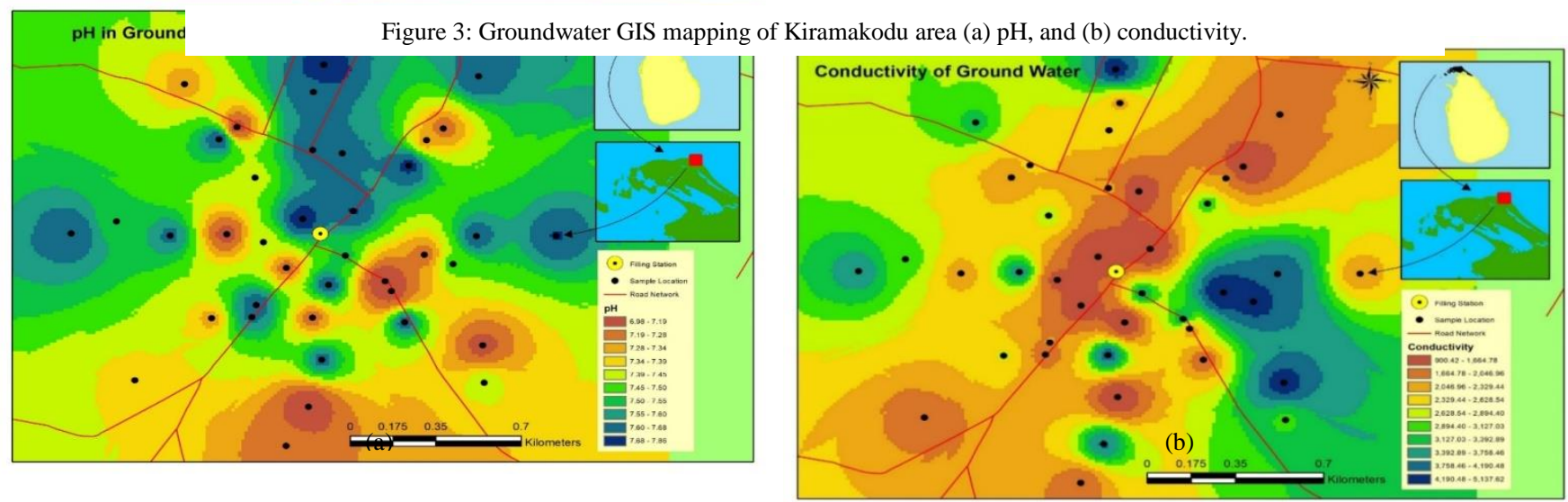
Figure 4: Ground water GIS mapping of Kiramakodu area (a) calcium, and (b) magnesium.

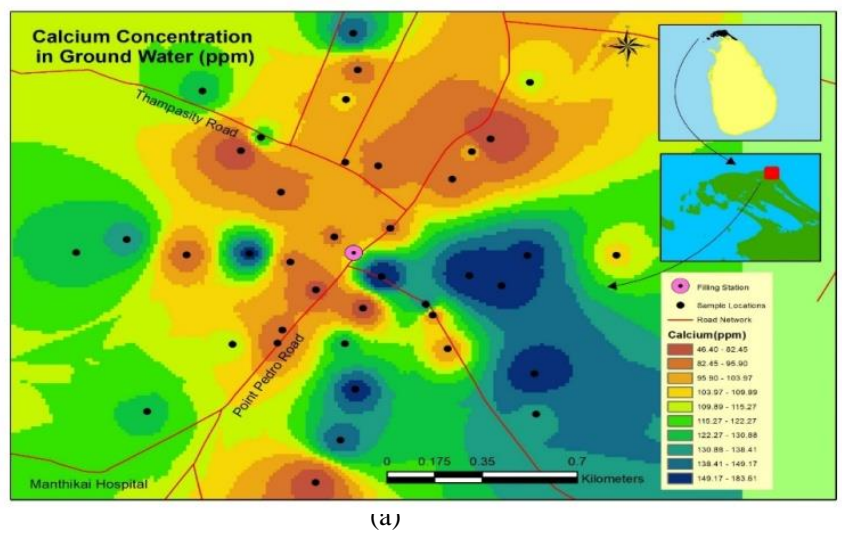

ppm. This may be due to the seawater intrusion into the groundwater and naturally occur from weathering of limestone, sedimentary rocks and calcium bearing minerals (WHO 2011) [10-17]. Some samples in the North, Northwest and Southwest showed low calcium content, ranges from $48.40 \mathrm{ppm}$ to $82.45 \mathrm{ppm}$. Most of the samples consist of high calcium concentration than the Sri Lankan standard for potable water which is $100 \mathrm{ppm}$. Amount of magnesium in $\mathrm{GW}$ was within the range of $8.19 \mathrm{ppm}$ to $60.81 \mathrm{ppm}$. The East direction possess a higher amount of magnesium ranging from $50.90 \mathrm{ppm}$ to $60.81 \mathrm{ppm}$. Groundwater samples near the service station showed low magnesium concentration when compared with other locations. But the amount of magnesium of most of the samples are within the range of Sri Lankan standard which is $30 \mathrm{ppm}$. Only four samples showed a high amount of magnesium may be due to the influence of seawater.

\section{Sodium and potassium}

The sodium and potassium are necessary for the human body function and associate with many physiological activities. Generally, sodium and potassium involve on the membrane of the muscular, and nervous system. Because, sodium and

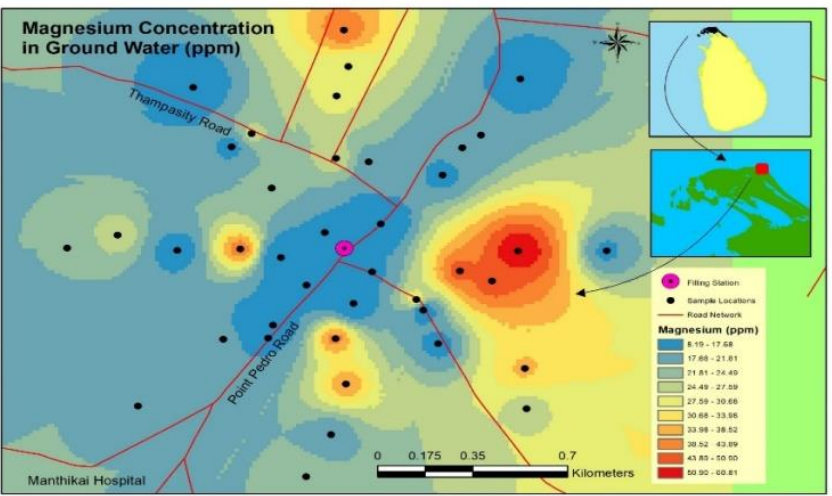

(b)

potassium are essential for information transmission, muscles functions and osmosis where extracellular and intracellular concentration varies with the functions. In addition, these electrolytes enhance the heart beats, regulate enzyme activity, maintain $\mathrm{pH}$, and involve redox reactions in the body. Hence, daily dietary requires these electrolytes and intake should be very small for which drinking water is one of the sources. Normal intake of the sodium per day should be $90-250 \mathrm{mEq}$ while potassium intake relay in the rage of the $3.5-5.0 \mathrm{mEq}$ per day. Because, sodium is the extracellular electrolyte while potassium is an intracellular composition in the body. The variation in concentration and ion flux generate a potential difference at the nervous membrane leads to progress of the impulse along the nerve. Excess amount of these electrolytes causes issues like pathological disorders, thirst, and edema whereas lowest amount causes symptoms like nausea, headache, vomiting and confusion. Moreover, the body conserve the sodium while there is no proper mechanism for the potassium conservation in the body. Hence, potassium and sodium are important for the complex healthier interplay of the body function [18-21]. The sodium content of GW ranging from $348.44 \mathrm{ppm}$ to $644.67 \mathrm{ppm}$. East, southeast and south directions shows the concentration of sodium between
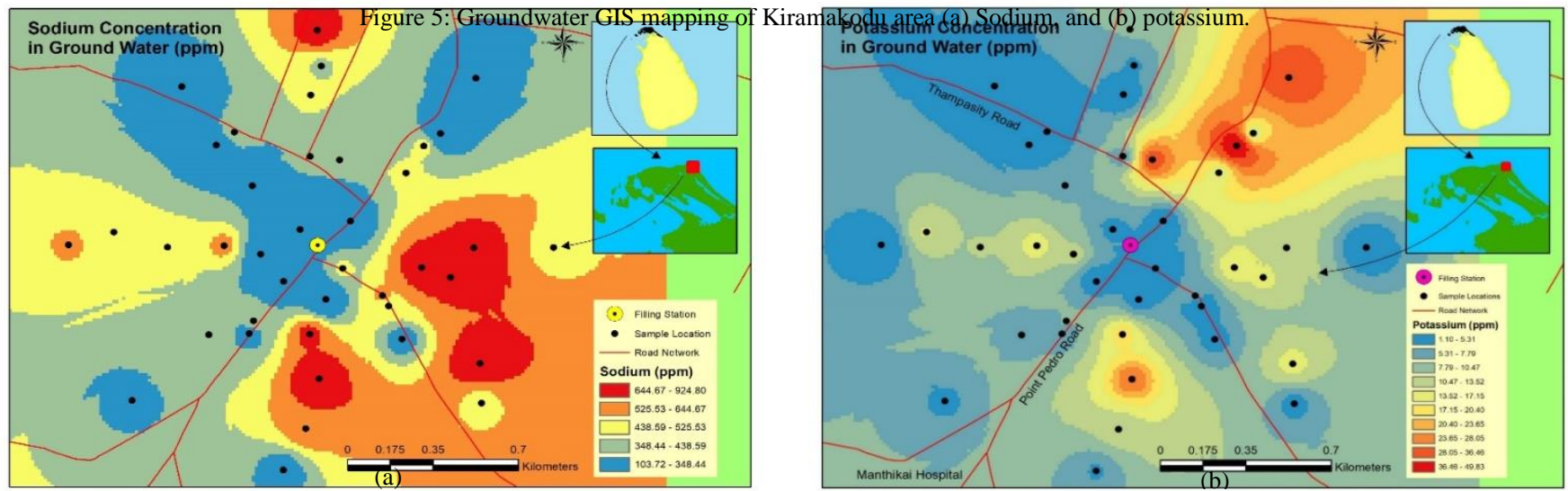

Vingnanam Journal of Science, Vol.15 (2), Dec 2020 
Figure 6: Ground GIS water mapping of Kiramakodu area (a) Chloride, and (b) Sulphate.

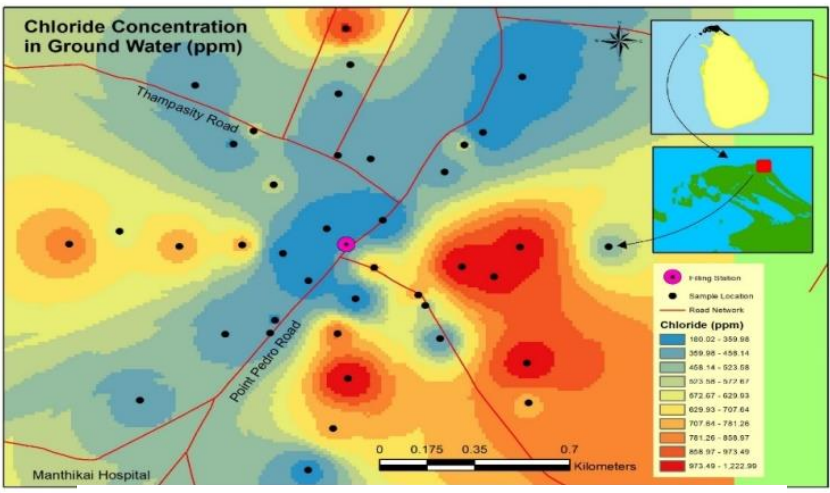

(a)

$525.53 \mathrm{ppm}$ and $924.80 \mathrm{ppm}$ which exceed the Sri Lankan standard $(200 \mathrm{mg} / \mathrm{L})$. This might be caused by seawater intrusion into the wells as it is a coastal area. Mineral deposits, seawater spray, sewage effluents can contribute significant quantities to water (WHO 1996). The concentration of potassium of the groundwater samples ranges from $1.10 \mathrm{ppm}$ to $49.83 \mathrm{ppm}$. Northeast direction showed higher concentration of potassium (20.40 - $49.83 \mathrm{ppm})$ and potassium concentration in ground water was within Sri Lankan standard. Only some points showed high values may be due to the seawater infiltration as this area is surrounded by sea. Some potassium compounds are used as fertilizers as a result of this groundwater may consist high amount of potassium. Increased potassium could result in significant health effects in people such as kidney disorders, heart diseases, coronary artery disease, hypertension, diabetes, and adrenal insufficiency (WHO 2009) [20, 21].

\section{Chloride and sulphate}

Sulfate and chloride are naturally available in the drinking water. The fluctuation of the sulfate and chloride make health concerns. Hence, maintaining the concentration of these ions in the body is crucial which can be taken via food and water in daily life. Further, a higher level of sulfate in drinking water causes diarrhoea and the excess amount of the chloride (250 $\mathrm{ppm})$ gives rise detectable taste. Sulfate reaches to groundwater by runoff rainwater via sulfate minerals while chloride reached seawater intrusion. The body maintains homeostasis with respect to sulfate and chloride presence in extracellular fluid maintained the osmosis pressure. The body loses $530 \mathrm{mg}$ of chloride per day and $9 \mathrm{mg} / \mathrm{kg}$ should be consumed by human for healthier life [22-23]. Amount of Chloride of the ground water samples were within the range of $180.02 \mathrm{ppm}$ to $1222.99 \mathrm{ppm}$. The East, Southeast and South directions show a high concentration of chloride compared to other sides which is due to the intrusion of seawater. In general, the coastal area possesses higher chloride compared to the inner land and Sri Lankan standard of chloride is 250 ppm which have a detectable taste (WHO 1996). According to the WHO report that the chloride concentration up to $150 \mathrm{ppm}$ is considered as good quality water while up to $150 \mathrm{ppm}$ is fair quality and over $500 \mathrm{ppm}$

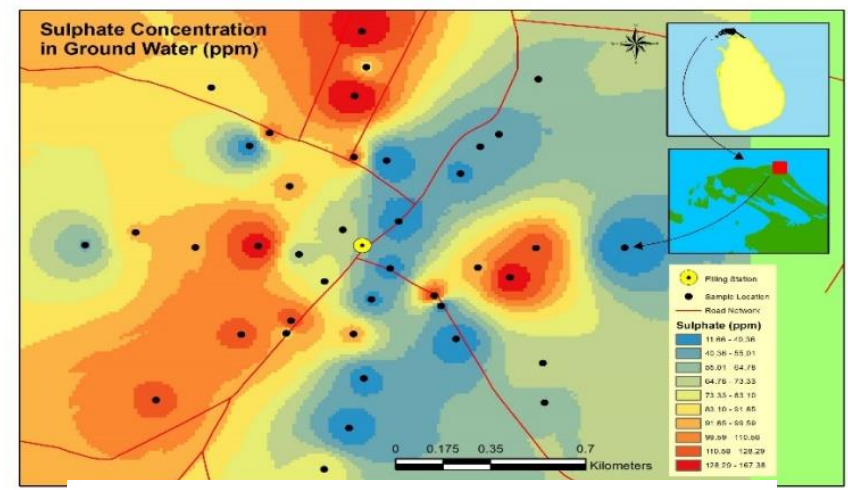

(b)

is considered as brackish water. The chloride increases EC of water and promotes corrosivity. In iron pipes, chloride reacts with metal ions to form soluble salts, thus increasing levels of metals in drinking-water and cause financial risk to maintain metal related construction in the area. In lead pipes, a protective oxide layer is built up, but chloride enhances galvanic corrosion. The sulfate varies between $11.66 \mathrm{ppm}$ to $167.38 \mathrm{ppm}$. The North, East and Southeast direction ground water exhibited 128.29 - $167.38 \mathrm{ppm}$ of sulphate content which is below the Sri Lankan standard of $250 \mathrm{ppm}$. The North and South direction directions showed low sulphate content (11.66 - 40.36) ppm. Sulfates occur naturally in numerous minerals, including barite $\left(\mathrm{BaSO}_{4}\right)$, epsomite $\left(\mathrm{MgSO}_{4} \cdot 7 \mathrm{H}_{2} \mathrm{O}\right)$ and gypsum $\left(\mathrm{CaSO}_{4} \cdot 2 \mathrm{H}_{2} \mathrm{O}\right)$. These dissolved minerals contribute to the mineral content of many drinking-waters. The sulfates are discharged into environment via mines, smelters, Kraft pulp, paper mills, textile mills and tanneries. There is a high risk of dehydration from diarrhoea that may be caused by high levels of sulfate in drinking (WHO 2016) [2023].

\section{E. Fat, oil and Grease (FOG) content}

Petroleum products are hydrocarbons have a variety of structural feature (simply aliphatic and aromatic) in which oil,

Figure 7: GIS mapping of Fat, oil and Grease (FOG) content in groundwater of Kiramakodu area

fats and grease are included. In addition, this FOG can be derived from plants and animals. The petroleum products are being used the various industrial area for variety of purposes. As petroleum produces possess different physiochemical

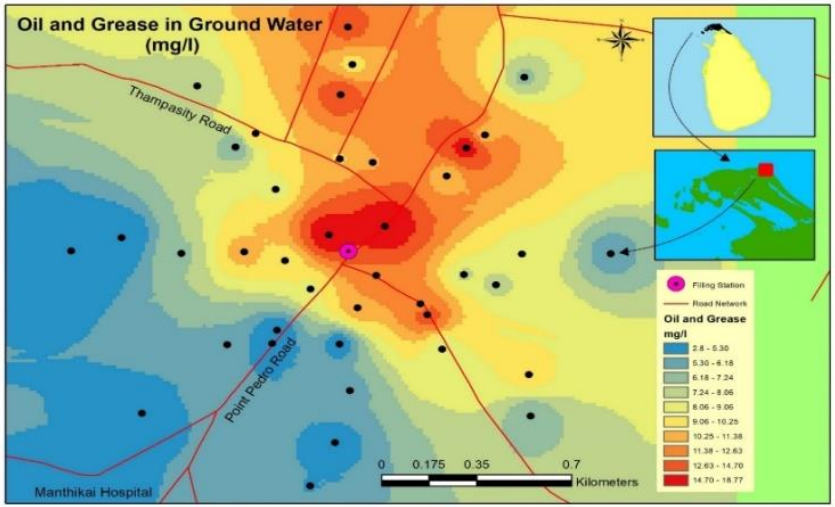


properties have a reflection on environment. Because, persistence in the environment depends on the volatility of petroleum products which depends on polarity, number of carbons, side chains and other structural features. The small amount of petroleum products has significant solubility in freshwater, especially, lightweight aromatic hydrocarbons have good solubility than high molecular weight one. The continuous spill of the hydrocarbon product into the freshwater source leads a higher amount of total hydrocarbon (TH) which causes unacceptable odors and taste. The varieties of methods are being used to analysis FOG in water and solvent extraction strategy was used.

Generally, alkanes have less health impact, however, continuous exposure such as hexane affects the nervous system irreversibly and carbon number E5-E12 have narcotic effect as well. In addition, the aromatic hydrocarbons are less toxic except benzene. Even though, polyaromatic hydrocarbons (PAH) are potential human carcinogens and induce skin tumor. However, methyl tertiary butyl ether (MTBE) has a less toxic effect, but earlier [11] reported that the precedence of the MTBE confirms the presence of the oil in the water and carried out the degradation of the BTEX in the water [5,11,24-25]. Though, this study selects particular aquifer for the study. Fat, oil and grease of groundwater samples range from $2.8 \mathrm{mg} / \mathrm{L}$ to $18.77 \mathrm{mg} / \mathrm{L}$. The FOG content near the service station was very high $(10.25$ - 18.7) $\mathrm{mg} / \mathrm{L}$. This is because of the waste oil from this service station is being discharged without any proper treatment over several decades and along the north direction also showed high FOG content. This confirmed that the direction of ground water flow is towards the Indian Ocean. Although, the south, southwest and west direction also exhibited the very low amount of FOG (2.8 - 5.30) $\mathrm{mg} / \mathrm{L}$. The waste oil contains poly aromatic hydrocarbons and high level of heavy metals which are carcinogenic and causes the health risk not only human but also other living organisms. In addition, the FOG includes nonvolatile petroleum carbons, waxes, animal fats, minerals, vegetable oils, soaps, sulfur compounds, organic dyes, and chlorophylls.

\section{CONCLUSION}

According to the results $\mathrm{pH}$ of the groundwater samples are slightly basic to acidic. Most of the samples in this area have high conductivity. Amount of sodium, chloride and calcium ions are high in most of the samples, especially near the sea. Due to the influence of the sea, the salinity of groundwater is high especially near the coastal area. Only some samples showed high potassium and magnesium concentration. Fat, oil and grease (FOG) content is high in the water samples near the service station and in North direction. Fat, oil and grease (FOG) carry a lot of heavy metal. So suitable precautions should be executed before it becomes a threatening to human health.

\section{AUTHORS' CONTRIBUTION}

Praveena Raveendran, and Kantahsamy Raagulan performed the experiment and write the manuscript (equal contribution), Kugamoorthy Velauthamurty design, and guide and check manuscript.

\section{FUNDING}

There is no external funding source.

\section{ACKNOWLEDGEMENT}

We thank all the laboratory staff of Department of Chemistry, University of Jaffna.

\section{CONFLICT OF INTEREST}

Authors declare no conflict of interest.

\section{REFERENCES}

Rahmanian, N., Ali, S.H.B., Homayoonfard, M., Ali, N.J., Rehan, M., Sadef, Y. and Nizami, A.S., 2015. Analysis of physiochemical parameters to evaluate the drinking water quality in the State of Perak, Malaysia. Journal of Chemistry, 2015.page1-10.

Thushyanthy Mikunthan, D., Vithanage, M., Pathmarajah, S., Ariyaratne, M.R. and Manthrithilake, H., 2013, Hydrogeochemical Characterization of Jaffna's Aquifer Systems in Sri Lanka, International Water Management Institute (IWMI). 69p. doi: 10.5337/2014.001

Mukherjee, S. and Halder, G., 2018. A review on the sorptive elimination of fluoride from contaminated wastewater. Journal of environmental chemical engineering, 6(1), pp.1257-1270.

Kulkarni, S., Dhokpande, S. and Kaware, J., 2015. A Review On Spectrophotometric Determination Of Heavy Metals With Emphasis On Cadmium And Nickel Determination By UV Spectrophotometry. International Journal Of Advanced Engineering Research And Science (IJAERS), 2(9).

Velauthamurty, K. and Kurukulasuriya, D.M., 2016. Quantitative analysis of fat, oil and grease in valikamam area, Sri Lanka and conversion of waste oil into grease.

Wanasinghe, W.C.S., Gunarathna, M.H.J.P., Herath, H.M.P.I.K. and Jayasinghe, G.Y., 2018. Drinking Water Quality on Chronic Kidney Disease of Unknown Aetiology (CKDu) in Ulagalla Cascade, Sri Lanka. Sabaragamuwa University, 16(1), pp.17-27.

Sri Lanka Standards for potable water - SLS 614: 2013

Tucker, C.S. and D'Abramo, L.R., 2008. Managing high pH in freshwater ponds. Stoneville: Southern Regional Aquaculture Center.

Šiler, P., Kolářová, I., Bednárek, J., Janča, M., Musil, P. and Opravil, T., 2018, June. The possibilities of analysis of limestone chemical composition. In IOP Conference Series: 
Materials Science and Engineering (Vol. 379, No. 1, p. 012033). IOP Publishing.

Roadcap, G.S., Kelly, W.R. and Bethke, C.M., 2005. Geochemistry of extremely alkaline $(\mathrm{pH}>12)$ ground water in slag - fill aquifers. Groundwater, 43(6), pp.806-816.

Ehanathan, S., Raagulan, K., Rajapakse, R.G. and Velauthamurty, K., 2020. Groundwater quality in the Jaffna peninsula of Sri Lanka and a qualitative study of BTEX removal by greenly synthesized iron nanoparticles-electrocatalyst system. Groundwater for Sustainable Development, p.100362.

Al Dahaan, S., Al-Ansari, N. and Knutsson, S., 2016. Influence of groundwater hypothetical salts on electrical conductivity total dissolved solids. Engineering, 8(11), pp.823-830.

Rodríguez-Rodríguez, M., Fernández-Ayuso, A., Hayashi, M. and Moral-Martos, F., 2018. Using water temperature, electrical conductivity, and $\mathrm{pH}$ to Characterize surfacegroundwater relations in a shallow ponds system (Doñana National Park, SW Spain). Water, 10(10), p.1406.

Addy, K., Green, L. and Herron, E., 2004. pH and Alkalinity. Kingston: University of Rhode Island.

Katawal, I., 2018. Lactobacillus salivarius L28 in dog kibble results in shifts in microbial indicators in pet fecal samples after feeding (Doctoral dissertation).

Cotruvo, J.A. and Bartram, J. eds., 2009. Calcium and magnesium in drinking-water: public health significance. World Health Organization.

Wijeyaratne, W.M. and Subanky, S., 2017. Assessment of the Efficacy of Home Remedial Methods to Improve Drinking Water Quality in Two Major Aquifer Systems in Jaffna Peninsula, Sri Lanka. Scientifica, 2017.

Pohl, H.R., Wheeler, J.S. and Murray, H.E., 2013. Sodium and potassium in health and disease. In Interrelations between essential metal ions and human diseases (pp. 29-47). Springer, Dordrecht.

World Health Organization, 2012. Guideline: Sodium intake for adults and children. World Health Organization.

World Health Organization, 2012. Guideline: potassium intake for adults and children. World Health Organization.

Newberry, S.J., Chung, M., Anderson, C.A., Chen, C., Fu, Z., Tang, A., Zhao, N., Booth, M., Marks, J., Hollands, S. and Motala, A., 2018. Sodium and potassium intake: Effects on chronic disease outcomes and risks.

Bashir, M.T., Ali, S.A.L.M.I.A.T.O.N. and Bashir, A.D.N.A.N., 2012. Health effects from exposure to sulphates and chlorides in drinking water. Pakistan J. of medical and health sciences, 3, pp.648-652.

Wang, J., Tao, T. and Yan, H., 2017. Effects of sulfate, chloride, and bicarbonate on iron stability in a PVC-U drinking pipe. International journal of environmental research and public health, 14(6), p.660.

World Health Organization (WHO), 2005. Petroleum products in drinking-water: background document for development of WHO guidelines for drinking-water quality.

Griffiths, C., Klemick, H., Massey, M., Moore, C., Newbold, S., Simpson, D., Walsh, P. and Wheeler, W., 2012. US Environmental Protection Agency valuation of surface water quality improvements. Review of Environmental Economics and Policy, 6(1), pp.130-146. 